medRxiv preprint doi: https://doi.org/10.1101/2020.11.26.20236489; this version posted November 30, 2020. The copyright holder for this preprint (which was not certified by peer review) is the author/funder, who has granted medRxiv a license to display the preprint in perpetuity. All rights reserved. No reuse allowed without permission.

\title{
The pathogenic p.(R391G) ABCC6 displays incomplete penetrance implying the necessity of an interacting partner for the development of pseudoxanthoma elasticum
}

Flora Szeri ${ }^{1,2,3}$, Agnes Miko ${ }^{4,5}$, Nastassia Navasiolava ${ }^{6}$, Ambrus Kaposi ${ }^{4,5}$, Shana Verschuere ${ }^{7}$, Qiaoli Li $^{1}$, Sharon F. Terry ${ }^{8}$, Federica Boraldi ${ }^{9}$, Jouni Uitto ${ }^{1}$, Koen van de Wetering ${ }^{1}$, Ludovic Martin $^{6}$, Daniela Quaglino 9,10 , Olivier M. Vanakker ${ }^{7}$, Kalman Tory ${ }^{4,5}$, Tamas Aranyi ${ }^{2,11}$ \#

${ }^{1}$ Department of Dermatology and Cutaneous Biology, The Sidney Kimmel Medical College, and The PXE International Center of Excellence in Research and Clinical Care, Thomas Jefferson University, Philadelphia, PA, USA

${ }^{2}$ Institute of Enzymology, RCNS, Budapest, Hungary

${ }^{3}$ Department of Biochemistry, Semmelweis University, Budapest, Hungary

${ }^{4}$ MTA-SE Lendület Nephrogenetic Laboratory, Budapest, Hungary

${ }^{5}$ Ist Department of Pediatrics, Semmelweis University, Budapest, Hungary

${ }^{6}$ PXE Consultation Center, MAGEC Nord Reference Center for Rare Skin Diseases, Angers

University Hospital, Angers, France

${ }^{7}$ Center for Medical Genetics, Ghent University Hospital, Ghent, Belgium

${ }^{8}$ PXE International, Washington, DC, USA

${ }^{9}$ Department of Life Sciences, University of Modena and Reggio Emilia, Modena, Italy

${ }^{10}$ Interuniversity Consortium for Biotechnologies (CIB), Italy

${ }^{11}$ Department of Molecular Biology, Semmelweis University, Budapest, Hungary.

\#Corresponding author

\begin{abstract}
$A B C C 6$ encodes a transmembrane transporter playing a primary role in the efflux of ATP from hepatocytes to the bloodstream. ATP is then cleaved to AMP and inorganic pyrophosphate, a major inhibitor of ectopic calcification. Pathogenic variants of $A B C C 6$ cause pseudoxanthoma elasticum, a multisystemic recessive ectopic calcification disease of variable severity. One of the mechanisms influencing the heterogeneity of a disorder is the penetrance of pathogenic variants. The penetrance of a sequence variant shows the proportion of individuals developing the expected phenotype in the presence of the variant. Incomplete penetrance indicates that the disease does not develop in all the cases when the pathogenic variant is present. Here, we investigated whether incomplete penetrance participates in the heterogeneity of pseudoxanthoma elasticum. By integrating the clinical and genetic data of 590 patients, we created the largest European pseudoxanthoma elasticum cohort. We identified two incomplete penetrant pathogenic variants, p.(V787I) and p.(R391G), based on their allele frequencies in our cohort and in the European reference population of gnomAD. The detailed characterization of the frequent $\mathrm{p} .(\mathrm{R} 391 \mathrm{G})$ pathogenic variant suggested only $2 \%$ penetrance with an unaltered severity of the clinical phenotype. Based on our biochemical analysis, we hypothesize that the variant becomes deleterious only if an interacting partner is mutated simultaneously. These data point to new molecular mechanisms by revealing the potential existence of the first interacting partner of ABCC6. Our data are important for genetic counseling
\end{abstract}

NOTE: This preprint reports new research that has not been certified by peer review and should not be used to guide clinical practice. 1 
medRxiv preprint doi: https://doi.org/10.1101/2020.11.26.20236489; this version posted November 30, 2020. The copyright holder for this preprint (which was not certified by peer review) is the author/funder, who has granted medRxiv a license to display the preprint in perpetuity. All rights reserved. No reuse allowed without permission.

of pseudoxanthoma elasticum, suggesting a much lower disease heritability of these pathogenic variants.

\section{Introduction}

ABCC6 encodes a transmembrane ATP binding cassette protein primarily expressed in the liver and to a lesser extent in the kidney and the intestines (1). The protein promotes the efflux of intracellular ATP to the bloodstream $(2,3)$. ATP is subsequently cleaved by a transmembrane ectonucleotidase, ENPP1, to AMP and pyrophosphate (PPi), which is a major inhibitor of ectopic calcification (4-6). The recessive loss-of-function pathogenic variants of ABCC6 lead to pseudoxanthoma elasticum (PXE, OMIM \#264800) (7-9), a slowly progressing disease. PXE is characterized by soft tissue calcification leading to dermatologic, ocular, and cardiovascular manifestations including vascular calcification, intermittent claudication, higher incidence of stroke and coronary artery disease $(10,11)$. The prevalence of PXE is $\sim 1 / 25,000-50,000(10,11)$ and over 300 pathogenic variants were reported in the several thousands of patients recruited worldwide by the PXE International patient organization and the European PXE reference centers $(12-14)$.

It has been reported for several monogenic diseases that some patients harboring a disease-causing genotype do not develop the clinical phenotype (15-18). This phenomenon is called incomplete penetrance. The proportion of patients among all individuals carrying the pathogenic variant determines the level of penetrance. The majority of pathogenic variants are fully penetrant, as all of the individuals with such variants are exhibiting the disease phenotype. However, for some mutations, penetrance can be significantly reduced, to even below $5 \%$, making genetic counseling challenging $(19,20)$.

Incomplete penetrance has been generally reported in autosomal dominant diseases where the increased expression of the wild-type allele by genetic, epigenetic or environmental factors can counterbalance the mutated allele (16-18). Nevertheless, incomplete penetrance has also been unraveled in recessive disorders in large pedigrees $(21,22)$. More recently, with the advent of the general use of genetic diagnosis, other examples have been found e.g. for cystic fibrosis (CFTR) (19), Wilson's disease (ATP7B) (23), and NPHS2-associated Steroid-Resistant Nephrotic Syndrome (24).

Incomplete penetrance can be assessed by the characterization of patient cohorts as well (25) requiring reference populations that are now available as a result of the worldwide sequencing efforts. Using a recently developed algorithm (Population genetics-based Penetrance Calculator (PoPeC) (26), which compares the allele frequencies of a patient cohort to a reference population, the penetrance of each pathogenic variant in the cohort can be assessed. Theoretically, in a disease with recessive inheritance the patient population solely contains disease-causing alleles. If a sequence variant in the patient cohort is not significantly more frequent (i.e. not significantly enriched) relative to the general population, it was likely erroneously considered to be pathogenic. However, the fold enrichment of the true disease-causing alleles in the patient cohort is generally similar for all completely penetrant pathogenic alleles. Nevertheless, it is possible that some sequence variants are significantly enriched in the patient cohort, which makes these variants likely pathogenic albeit they are significantly less enriched than the other pathogenic alleles. These 
medRxiv preprint doi: https://doi.org/10.1101/2020.11.26.20236489; this version posted November 30, 2020. The copyright holder for this preprint (which was not certified by peer review) is the author/funder, who has granted medRxiv a license to display the preprint in perpetuity. All rights reserved. No reuse allowed without permission.

alleles are disease-causing but exhibit incomplete penetrance. Individuals harboring the incomplete penetrant allele can therefore manifest the disease or can also be completely free of the symptoms (26).

PXE is characterized by high interindividual heterogeneity even within a single family (27). Although the molecular mechanisms behind this excessive variability are elusive, epigenetic and environmental factors are suspected to play a role in this phenomenon. In the present study we investigated whether pathogenic PXE alleles exhibit incomplete penetrance. We studied phenotypically and genotypically characterized patient cohorts to shed more light on the mechanism of the disease and improve genetic counseling in PXE.

\section{Methods}

\section{Patients}

PXE patients signed an informed consent. The study was approved by the University Hospital of Angers, the Ethics Committee of the University of Ghent, and the local Ethics Committee for the University of Modena and Reggio Emilia and the Declaration of Helsinki was followed. The US patients were recruited under the IRB of Thomas Jefferson University, PA and the Genetic Alliance IRB - protocol PXE \#001. Patients were clinically diagnosed as described earlier (27)(28, 29). Mutation detection was performed to distinguish pseudogenes from the $A B C C 6$ gene and determine large deletions (29-31). Briefly, genomic DNA was isolated from whole blood

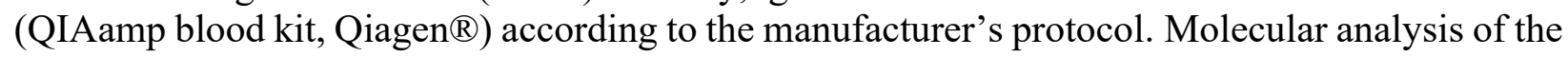
coding sequence and the intron-exon boundaries of the $A B C C 6$ gene was performed as previously described $(28,32)$. C-notations are based on NM_001171.5 and p-notations on NP_001162.4. MLPA analysis of the $A B C C 6$ gene was performed to evaluate the presence of larger deletions or insertions by using commercially available SALSA MLPA kit PO92-B3 (MRCHolland) and according to the manufacturer's recommendations (www.mlpa.com). Altogether 397 female and 191 male patients were included in the European cohort. The US cohort was composed of 436 patients.

\section{Bioinformatic analysis}

Bioinformatic analysis was performed by using the PoPeC tool, as described earlier (26) and in the text. Briefly, the unified patient cohorts underwent allelic sequence variant enrichment analysis relative to the European non-Finnish population of the gnomAD database. Significantly enriched alleles were tested for incomplete penetrance by PoPeC. The allele frequency of each significantly enriched (Fisher-exact test) variant was compared to the allele frequencies of definitely fully penetrant complete loss-of-function (LOF) sequence variants. We considered the variant incompletely penetrant if the result of the comparison was lower than $30 \%$, and significant after Bonferroni correction for multiple testing.

\section{Cell culturing and generation of mutant cell lines}

HEK293 cells were cultured at $37^{\circ} \mathrm{C}$ and $5 \% \mathrm{CO}_{2}$ in humidifying conditions in HyClone DMEM (GE) completed with 100 units pen/strep per ml (Gibco) and 5\% FBS. Site-specific mutations were introduced into in pEntr223-rAbcc6 plasmid (3) by Uracil excision-based (USER) cloning (33) with the following reverse and forward primers: ACCTTTCCGUACACCAGGCCAGTGATGGC and ACGGAAAGGUCCTGGTCCTGTCCAGTGGTTCCA, respectively. The cDNA encoding 
medRxiv preprint doi: https://doi.org/10.1101/2020.11.26.20236489; this version posted November 30, 2020. The copyright holder for this preprint (which was not certified by peer review) is the author/funder, who has granted medRxiv a license to display the preprint in perpetuity. All rights reserved. No reuse allowed without permission.

the pEnter223-rAbcc6 R389G mutant were sequenced and subsequently subcloned into a Gateway compatible pQCXIP expression vector and were transfected into HEK293 cells with calcium phosphate precipitation method. The transfected cells were selected in completed DMEM medium also containing $2 \mu \mathrm{M}$ puromycin. After puromycin selection the expression of the R389G rat ABCC6 in isolated cell clones was confirmed by immunoblot analysis and compared to that of the wild-type rat ABCC6 cell line. For the functional assays HEK293 cell lines were seeded in polyD-lysine-coated 96-well plates in $100 \mu 1$ of completed DMEM, and experiments were conducted with wells using cells forming confluent monolayers.

\section{Immunoblot analysis of wild-type and mutant rat $A B C C 6$}

Cell lysates were prepared in lysis buffer $(10 \mathrm{mM} \mathrm{KCl}, 10 \mathrm{mM}$ Tris- $\mathrm{HCl}$ and $1.5 \mathrm{mM} \mathrm{MgCl}, \mathrm{pH}$ 7.4) supplemented with protease inhibitors (Roche). Samples containing $5 \mu \mathrm{g}$ of total protein determined by BCA assay (Pierce ${ }^{\mathrm{TM}}$ BCA Protein Assay Kit, Thermo Scientific) were separated on $7.5 \%$ SDS-polyacrylamide gels (Bio-Rad) and transferred to a PVDF membrane with a semidry system (Bio-Rad). Wild-type and mutant rat ABCC6 were detected with the polyclonal K14 rabbit anti-rat ABCC6 antibody diluted by 1:3000 (kind gift of Dr. Bruno Stieger and HRPconjugated donkey anti-rabbit secondary antibody (SA1200 Fisher Scientific) in a 1:5000 dilution. The signal was visualized by ECL (Pierce Western blotting substrate, Thermo Scientific).

\section{Subcellular localization of rat ABCC6 in HEK293 cells}

Rat ABCC6 was detected as described previously(34). In short, HEK293 cells were seeded and grown for 2 days on ibi-Treat $1.5 \mu$-Slide 4 well chamber slides (80426, Ibidi) previously coated with poly-D-lysine. Cells were fixed in $4 \%$ PFA and subsequently in $-20{ }^{\circ} \mathrm{C}$ cold methanol for 5 min each. Samples were blocked with Protein Block solution (BioGenex) for $60 \mathrm{~min}$. Coverslips were incubated with the polyclonal rabbit anti-rat ABCC6 antibody K14 diluted by 1:100 (kind gift of Dr. Bruno Stieger) and the mouse monoclonal anti-alpha 1 sodium potassium ATPase antibody (ab7671, Abcam) diluted by 1:250 for $60 \mathrm{~min}$. Subsequently, samples were incubated with A488-conjugated anti-rabbit secondary antibody (A11008, Fisher Scientific) and A568 conjugated anti-mouse antibody (A11004, Fisher Scientific) both diluted by 1:1000 for $60 \mathrm{~min}$. Samples were subsequently incubated with 300nM DAPI (40043, Biothium) for 5min to stain nuclei. The intracellular localization of the wild type and mutant rat ABCC6 were analysed by two point-scanning laser confocal microscope Nikon Eclipse Ti equipped with a Nikon A1R+ at the Bioimaging Shared Resource of the Sidney Kimmel Cancer Center (NCI 5 P30 CA-56036).

\section{Quantification of PP levels in the medium of cells}

Confluent HEK293 cells in 96-well plates were incubated in fresh medium for 24 hours. $\mathrm{PP}_{\mathrm{i}}$ concentration of the medium samples were determined as described previously (35). First, PPi was converted into ATP in an assay containing $50 \mathrm{mM}$ HEPES pH 7.4, $80 \mu \mathrm{M} \mathrm{MgCl}_{2}, 32 \mathrm{mU} / \mathrm{ml}$ ATP Sulfurylase (New England Biolabs) and $16 \mu \mathrm{M}$ adenosine 5' -phosphosulfate (Sigma-Aldrich) by incubating samples and standards at $37^{\circ} \mathrm{C}$ for $30 \mathrm{~min}$ followed by inactivation of the enzyme at $90^{\circ} \mathrm{C}$ for 10 minutes. In a consecutive step, ATP content was determined in a bioluminescent assay adding BacTiterGlo (Promega,) to samples and standards in a 1:1 ratio. PPi concentration of plasma samples was calculated with standard calibration. Values were corrected for the initial sample ATP concentrations.

Real-time ATP efflux assay 
medRxiv preprint doi: https://doi.org/10.1101/2020.11.26.20236489; this version posted November 30, 2020. The copyright holder for this preprint (which was not certified by peer review) is the author/funder, who has granted medRxiv a license to display the preprint in perpetuity. All rights reserved. No reuse allowed without permission.

Real-time ATP efflux assay were conducted as described previously (35). HEK293 cells seeded in poly-D-lysine-coated black $96-$-well plates with an optically clear bottom were allowed to grow to confluence in 2 days in completed DMEM medium. At confluency the medium was removed and replaced by $50 \mu \mathrm{l}$ efflux buffer, consisting of $11.5 \mathrm{mM}$ HEPES (pH 7.4), $130 \mathrm{mM} \mathrm{NaCl}, 5$ $\mathrm{mM} \mathrm{MgCl} 2,1.5 \mathrm{mM} \mathrm{CaCl}_{2}$ and $11.5 \mathrm{mM}$ glucose. Cell were incubated for 1 hour at $27^{\circ} \mathrm{C}$ in efflux buffer. Next, $50 \mu \mathrm{l}$ efflux buffer containing 10\% BactiterGlo (Promega) reactant previously dissolved in efflux buffer according to the instructions of the manufacturer was added to each well. Bioluminescence was subsequently determined in real time in a Flex Station 3 microplate reader (Molecular Devices). The real-time ATP efflux assay was run at $27^{\circ} \mathrm{C}$ for the first 1 hour and then at $37^{\circ} \mathrm{C}$ for 2 hours. The initial low temperature allowed the endogenous ectonucleotidases to metabolize the excess ATP generated by medium-change initiated sheer-stress resulting to an ABCC6-independent ATP efflux, that otherwise gave a significant background in the experiments.

\section{Statistical analyses}

Data were analyzed using Prism 8.4.2 (GraphPad Software Inc.) Correlation between age and Phenodex score was assessed by linear regression with $95 \%$ confidence intervals. Two-tailed t-test was applied to test significance of pyrophosphate concentrations of HEK293 cells overexpressing the wild type or the p.(R391G) variant. Significance was accepted at $\mathrm{p}<0.05$.

\section{Results}

\section{Assembly of the largest European patient cohort}

To investigate the penetrance of the reported PXE-causing pathogenic variants, we first compiled an anonymized cohort of previously clinically and genetically diagnosed PXE patients. In the cohort we only included patients of known ethnic origin and familial relationship, and with two identified $A B C C 6$ variants considered to be disease-causing at the time of diagnosis. Importantly, patients with only one identified ABCC6 pathogenic variant were not included in the database even though digenic inheritance of PXE was reported earlier (36-38). Altogether 590 probands with European ancestry from three different countries (Belgium, France, and Italy $(27,28)$ ) were included (Supplementary Table 1). The age and clinical scoring of the PXE phenotype by the Phenodex system (based on dermatologic, ocular, gastrointestinal, vascular, and cardiac symptoms) (29) were available for all patients (Supplementary Table 1).

\section{Analysis of the ABCC6 sequence variants}

In the next step, we used the PoPeC algorithm, developed recently by Miko et al. (26) to evaluate the penetrance of reported pathogenic variants in Mendelian disorders in well characterized cohorts. At the initial part of the analysis the algorithm performs filtering of the patients in a few consecutive steps to avoid skewed overrepresentation of some alleles by including several members of the same family. Patients with indels $>50 \mathrm{bp}$ were also excluded because the gnomAD database used as the reference population in the next steps does not include these pathogenic variants. As a result of the filtering from the initial 590 patients 616 alleles remained. 
medRxiv preprint doi: https://doi.org/10.1101/2020.11.26.20236489; this version posted November 30, 2020. The copyright holder for this preprint (which was not certified by peer review) is the author/funder, who has granted medRxiv a license to display the preprint in perpetuity. All rights reserved. No reuse allowed without permission.

Subsequently, the PoPeC algorithm performs an enrichment analysis on the remaining sequence variants by comparing their allele frequency (AF) within the patient population and the European non-Finnish population of the gnomAD database (https://gnomad.broadinstitute.org) (39). Figure $1 \mathrm{~A}$ and Supplementary Table 2 illustrate the results of this analysis. The solid line marks the 1 times enrichment threshold with the theoretical values representing equal AF in the patient and the reference populations in Figure 1A. The dashed and punctuated lines represent 10- and 100 times enrichment, respectively. The majority of the 616 alleles in the patient cohort are present as a single cluster, far above the 1 times enrichment threshold, demonstrating full penetrance and probable pathogenicity of these alleles. In this cluster the following variants were represented by at least 10 alleles $(A F>1.5 \%)$ : p. $\left(R 518^{*}\right)(n=28)$, p.(R518Q) $(n=26)$, p. (Q378*) $(n=18)$, c. (G3736$1 \mathrm{G}>A)(\mathrm{n}=12)$, p. $(\mathrm{R} 1138 \mathrm{~W})(\mathrm{n}=12)$. Altogether, we found that the majority of the previously reported pathogenic variants were indeed significantly enriched in the patient cohort relative to the general population. Furthermore, most of them were present in several patients without familial relationship.

Strikingly, our analysis identified some variants as outliers, located below the 1 times enrichment threshold [p.(R1268Q), p.(R265G), c.3507-3C>T, p.(L946I), c.346-6G >A]. Accordingly, they are more frequent in the general population than in the patient population and thus per definition must represent benign, non-pathogenic variants, and were probably mistakenly identified as diseasecausing. We excluded these variants from further investigations.

We also observed two further outliers from the cluster of the pathogenic variants. One of them corresponded to p.(R1141*), which had a high AF both in the general and the patient population. This variant showed an enrichment of approximately 125 -fold in the patient population and was responsible for almost $1 / 3$ of all mutations. This is a well-known, particularly frequent pathogenic variant. The other outlier pathogenic variant we observed, p.(R391G), was unexpected. It had a high AF in the general population $(0.78 \%)$ and showed a small but significant enrichment amongst patients $\left(2.89\right.$-fold enrichment; $\left.\mathrm{p}=5 \times 10^{-4}\right)$. However, this enrichment remained close to 1 (Figure 1A), which raised the possibility that this variant is incompletely penetrant.

\section{Identification of incomplete penetrant variants}

In the second part of the analysis we performed the incomplete penetrance test on the remaining alleles. The PoPeC algorithm compared the allele frequency of each variant to the allele frequencies of definitely fully penetrant complete loss-of-function sequence variants (LOF), where no full length ABCC6 is present. We considered a pathogenic variant incompletely penetrant if the result of the comparison was lower than 30\%, a threshold set arbitrarily (26). From the different variants we identified two variants as being incomplete penetrant: p.(V787I) and p.(R391G). The p.(V787I) was present only in two patients from the original French cohort but was enriched significantly relative to the general population $(9.53$-fold; $p=0.02)$. Nevertheless, this enrichment was much less prominent than that of the LOF pathogenic variants (Figure 1A Supplementary Table 3), demonstrating potential incomplete penetrance of the p.(V787I) $\left(6.5 \% ; \mathrm{p}<5.1^{*} 10^{-8}\right)$, suggesting that in $>90 \%$ of the cases the presence of this pathogenic variant does not lead to the development of PXE. 
medRxiv preprint doi: https://doi.org/10.1101/2020.11.26.20236489; this version posted November 30, 2020. The copyright holder for this preprint (which was not certified by peer review) is the author/funder, who has granted medRxiv a license to display the preprint in perpetuity. All rights reserved. No reuse allowed without permission.

In the followings we focused on p.(R391G), the other pathogenic variant found to be incomplete penetrant, which is the second most frequent missense mutation in our patient cohort (17 patients from 590). We identified p.(R391G) as slightly but significantly enriched. After calculating the penetrance of this variant, we found a $2 \%$ penetrance $\left(\mathrm{p}<2.6^{*} 10^{-118}\right)$ suggesting that out of 100 individuals carrying a completely penetrant pathogenic variant on one allele and the p.(R391G) on the other, only $\sim 2$ would develop PXE.

As a validation of the incomplete penetrance of the p.(R391G) pathogenic variant, we used a second PXE cohort. This cohort was similar in size to the first one and was composed of 436 patients from the United States. Most of the patients were of European ancestry however, familial relationship and precise ethnicity were not available. Therefore, we only used these patients as a confirmatory cohort instead of combining it with the first one. Eleven patients were compound heterozygous for the p.(R391G) sequence variant in this cohort. Five additional patients with the p.(R391G) variant and without an identified second pathogenic variant were also present in this cohort indicating an almost identical AF for p.(R391G) in the US and the European PXE cohorts. Comparing these data to the same European gnomAD population suggested a similar incomplete penetrance than in the first cohort.

In order to assess the severity of the PXE phenotype in the presence of the p.(R391G) pathogenic variant, we studied the available clinical data based on the Phenodex scores (29). We compared the Phenodex score of patients from the European cohort being compound heterozygous for p.(R391G) with those having two LOF alleles (2xLOF). Here, we also included patients with large deletions not represented in the gnomAD database and all members of the same family to increase the power of this comparison. After plotting the Phenodex scores in the function of age (Figure 1B), we performed linear regression on both groups. Not surprisingly, our analysis demonstrated that the phenotype is linearly correlated with age, suggesting a progressive aggravation of the clinical symptoms. The parameters of the fitted lines $\left(\mathrm{Y}_{2 \times \mathrm{LOF}}=(0.062 \pm 0.007) * \mathrm{X}+2.182 \pm 0.323\right.$; $\left.\mathrm{Y}_{\mathrm{R} 391 \mathrm{G}}=(0.080 \pm 0.024) * \mathrm{X}+0.633 \pm 1.175 ; \mathrm{R}^{2}{ }_{2 \times L O F}=0.551, \mathrm{R}^{2}{ }_{\mathrm{R} 391 \mathrm{G}}=0.452\right)$ were not significantly different. This implies that patients with the p.(R391G) variant have the same disease severity compared to patients with the most debilitating pathogenic PXE variants. Furthermore, this also indicates that the disease progression is not different between patients with $2 x L O F$ alleles and patients being compound heterozygous for p.(R391G).

\section{Genetic mechanisms of incomplete penetrance}

Next, we undertook to explain the unique behavior of the p.(R391G) sequence variant in the $A B C C 6$ gene. First, we disclosed the possibility of the identification of this incomplete penetrant pathogenic variant as a result of a sequencing artefact. $A B C C 6$ has two human-specific pseudogenes, both containing only a few 5' exons, that are almost $100 \%$ identical to the functional $A B C C 6$ gene and are both expressed $(30,31)$. While pseudogene 2 ends much more upstream than the $9^{\text {th }}$ exon where the pathogenic variant is located, pseudogene 1 contains the corresponding region, thus it was theoretically possible that the observed increased AF $(0.78 \%)$ in the reference population is due to artefactual sequencing of the pseudogene 1 instead of the $A B C C 6$ gene. However, the codon for the R391 residue and its flanking regions are fully identical in pseudogene 1 and the functional gene, excluding the possibility of an artefactually increased AF of the pathogenic variant in the gnomAD database. 
medRxiv preprint doi: https://doi.org/10.1101/2020.11.26.20236489; this version posted November 30, 2020. The copyright holder for this preprint (which was not certified by peer review) is the author/funder, who has granted medRxiv a license to display the preprint in perpetuity. All rights reserved. No reuse allowed without permission.

In the followings, we tested whether the observed incomplete penetrance of the pathogenic variant could be explained by an effect on splicing, which frequently causes reduced penetrance (40-43) or by its obligate association with another pathogenic variant in the $A B C C 6$ gene. The p.(R391G) pathogenic variant is localized in the proximity of the 3 ' end of the exon 9 of the gene (n-5 bp). Although it is close to the end of the exon, it is also sufficiently far to disclose that it is involved in alternative splicing according to splice site prediction (ASSP) (44). This could not be further confirmed by gene expression analysis due to the absence of patient tissue samples, as the gene is primarily expressed in the liver. From the available data we therefore concluded that the pathogenic variant does not lead to altered splicing (see discussion).

Next, we tested the potential association of p.(R391G) with any specific pathogenic variant of $A B C C 6$ on the other allele. We found that from the initial 17 European patients with p.(R391G) only 3 had various missense pathogenic variants on the other allele, while all others were associated with LOF pathogenic variants. This result ruled out the specific association of a missense variant on the $2^{\text {nd }}$ allele in PXE patients with p.(R391G). Next, we investigated whether p. $(\mathrm{R} 391 \mathrm{G})$ is more prone to be associated with truncating than missense variants. In the original European patient cohort, there were almost 2 times more LOF pathogenic variants compared to missense pathogenic variants. In the filtrated table of 616 alleles $58 \%$ of the pathogenic variants were truncating (345 vs 247 after exclusion of the 14 remaining patients with p.(R391G) alleles). The association of LOF variants with the incomplete penetrant allele (11/14) was therefore not significantly increased relative to the proportion of LOF pathogenic variants in the patient cohort $(p=0.17)$. Altogether we therefore did not observe any pathogenic variants associated with the incomplete penetrant allele.

As a result, we hypothesized that the R391 residue is involved in a pivotal intramolecular interaction. We assume that this interaction is altered by the substitution of arginine by glycine only if another residue is also mutated in $A B C C 6$. This hypothesis was supported by the analysis of the conservation of the R391 residue and homology models of ABCC6. The R391 and flanking residues of the exon 9 and 10 are well conserved throughout the evolution (Figure 2A) suggesting that R391 and the neighboring amino acids are indeed important for the correct functioning of the protein (Clustalw) (45). Furthermore, R391 is also conserved in other members of the ABCC family ( $\mathrm{ABCC} 1, \mathrm{ABCC} 3$, and $\mathrm{ABCC} 4)$, while it is replaced by the similarly charged lysine in ABCC2 and ABCC7 (CFTR) (46) (Figure 2 B). The position of the R391 amino acid residue according to the most recent homology model built on the crystal structure of the bovine ABCC1 protein indicates that the residue is in the $4^{\text {th }}$ intracellular loop at the cytoplasmic surface of the protein (47). Furthermore, the model suggested that R391 and the entire loop has a different localization in the inward and the outward facing conformations of the transporter, suggesting a potential role of this domain in the conformational switch of the protein necessary for the function of ABCC6. Furthermore, the model revealed the intramolecular interactions of R391 with V249, E253, V1147, and N1151 residues. Based on these findings we tested whether there was an association with the coding SNPs detected during analysis of the $A B C C 6$ gene in the patients with the p.(R391G) pathogenic variant. This analysis did not reveal any R391G associated SNPs in $A B C C 6$ either the European or the US patients. We therefore concluded, that the disease-causing mechanism of the p. $(\mathrm{R} 391 \mathrm{G})$ pathogenic variant is not based on the alteration of an intra-protein 
medRxiv preprint doi: https://doi.org/10.1101/2020.11.26.20236489; this version posted November 30, 2020. The copyright holder for this preprint (which was not certified by peer review) is the author/funder, who has granted medRxiv a license to display the preprint in perpetuity. All rights reserved. No reuse allowed without permission.

interaction due to the presence of a simultaneous pathogenic variant of a second amino acid in the $A B C C 6$ gene.

\section{Functional characterization of the incomplete penetrant variant}

Finally, we performed functional in vitro tests on the mutated ABCC6 protein. We hypothesized that the p.(R391G) ABCC6 would behave similarly to the wild-type protein in these experiments since the penetrance of the pathogenic variant is only $\sim 2 \%$ and in $98 \%$ of the cases no phenotype is observed in individuals carrying the variant. It was therefore unlikely, that the cell line we were using in our experiment would harbor the alteration that allowed the manifestation of the disease phenotype. For this critical experiments we used the rat ABCC6 protein, which was previously shown to be significantly more active than the human ortholog, with the region of interest being fully conserved $(2,3)$. Of note, the residue homologous to the human R391 in rat is R389 (Figure 2A). We have therefore overexpressed the rat wild-type and the rat p.(R389G) ABCC6 in HEK293 cells in order to determine the plasma membrane localization and functional activity of the proteins. The expression levels of the proteins were compared by Western-blot analysis in different clones and found to be similar (Figure 3A). Additionally, we observed similar plasma membrane localization of the overexpressed wild-type and p.(R389G) mutant ABCC6 (clone A2) (Figure 3B). This suggested that the p.(R391G) human pathogenic variant did not alter the localization of the protein confirming our expectations and further supporting the hypothesis that the identified pathogenic variant is indeed incompletely penetrant.

To further characterize the p.(R389G) sequence variant, we carried out biochemical tests on the overexpressing HEK293 cells, using the rat ABCC6 p.(R389G) clone A2, exhibiting similar expression level compared to the wild-type rat ABCC6. According to our current knowledge ABCC6 mediates efflux of ATP from the cytoplasm to the extracellular space (2). The ABCC6mediated ATP efflux can be determined in real time in the medium of HEK293 cells overexpressing the wild-type ABCC6 (2). The real-time ATP efflux mediated by HEK293 overexpressing the rat p.(R389G) sequence variant was not significantly different from that of the wild type rat protein, but was significantly different from parental HEK293 cells, that did not exhibit ATP efflux (Figure 3C). The extruded ATP is rapidly cleaved to PPi and AMP by the membrane bound exoenzyme Ectonucleotide Pyrophosphatase/Phosphodiesterase 1 (ENPP1), a transmembrane ectonucleotidase expressed in several cell types including HEK293 cells $(3,35)$. Therefore, in end point experiments, we measured the accumulation of PPi in the culture medium (Figure 3D). As expected, the overexpressed rat p.(R389G) variant in HEK293 cells showed no altered characteristics neither in the real-time ATP assay nor in the PPi levels measured from the medium. These data indicate that the pathogenic variant itself does not directly alter the activity of the protein. This also suggests that ABCC6 may interact with other protein(s), which might play a decisive role in the development of PXE when ABCC6 harbors the p.(R391G) pathogenic variant.

\section{Discussion}

In the present study we generated the largest European cohort of almost 600 anonymized PXE patients based on previously published data from three European countries (Belgium, France, and Italy) $(27,28)$. The analysis of this cohort by PoPeC revealed that p.(R391G) and potentially p.(V787I) as well are incomplete penetrant revealing new layers of heterogeneity of PXE. Our 
medRxiv preprint doi: https://doi.org/10.1101/2020.11.26.20236489; this version posted November 30, 2020. The copyright holder for this preprint (which was not certified by peer review) is the author/funder, who has granted medRxiv a license to display the preprint in perpetuity. All rights reserved. No reuse allowed without permission.

biochemical and microscopic analyses showed no functional difference between the wild-type and the tested rat p.(R389G) variant in HEK293 cells.

To identify potential incomplete penetrant PXE-causing pathogenic variants of ABCC6, the recently created $\mathrm{PoPeC}$ tool was used. PoPeC, to avoid artefacts, uses very stringent exclusion criteria. For instance, among others, it corrects for overrepresented homozygous pathogenic variants and therefore, only $52 \%$ of the initial alleles passed the filtering criteria. As a result of enrichment calculations five variants were found to be more frequent in the reference population than in the patient cohort, we can therefore claim that these are non-pathogenic benign variants although identified in the literature previously as pathogenic. Some other variants [p.(G1327R), p.(A950T), p.(G1327E), p.(A452D), p.(E699K), p.(R1339H)] were enriched in the patient cohort, but not significantly. Larger well-characterized patient cohorts will be required to determine their pathogenicity, especially because the p-value of their enrichment for all except p.(G1327R) was below 0.1 . The pathogenicity of these variants was assessed recently by the Sherloc scoring system and the p.(R1339H) was found to be pathogenic while the others were classified as likely benign and of unknown significance (48) however, the algorithm used in our study calculates penetrance only on alleles significantly enriched in the patient population.

The two incompletely penetrant pathogenic variants identified in this study were the p.(V787I) and p. $(\mathrm{R} 391 \mathrm{G})$ sequence variants with calculated $6.5 \%$ and $1.98 \%$ penetrance, suggesting that only $6.5 \%$ and $\sim 2 \%$ of the carriers having another loss-of-function pathogenic variant develop PXE, respectively. Can we consider pathogenic variants with such a small penetrance as real diseasecausing sequence variants? Despite of their low level of penetrance, we propose, that these variants are real pathogenic variants. Indeed, similarly low penetrance of disease-causing pathogenic variants has been reported previously for several other genes exhibiting both autosomal dominant and autosomal recessive inheritance $(19,20)$.

Nevertheless, it should be emphasized that the p.(V787I) was reported previously in only one patient (29) and is present solely in two patients of our cohort, both originating from France. Due to the small number of patients harboring this pathogenic variant it was impossible to compare the severity of their phenotype to the biallelic LOF pathogenic variant phenotype. The V787 residue was previously shown to be evolutionarily conserved (46). Of note, based on protein glycosylation and expression studies it has also been suggested recently that the p.(V787I) ABCC6 has similar localization to the wild-type ABCC6 (46). Functional studies of the variant will be required once its incomplete penetrance will be further confirmed.

We investigated in more detail the p.R391G pathogenic variant, which has a much higher AF in the patient population. To assess the clinical symptoms of the patients with one p.(R391G) pathogenic variant we made use of the Phenodex scoring (29). Though the Phenodex scoring is somewhat debated, it is the most widely used tool for clinical evaluation of PXE. Although the number of patients with p.(R391G) was relatively small and a bigger cohort would better confirm these results, our data showed that the p.(R391G) pathogenic variant, when it leads to PXE, the disease phenotype is as severe as the one caused by the ABCC6 LOF variants. This also suggests, that in rare cases $\left(A F_{\text {in patients }}{ }^{2}=\sim 1 / 2500\right.$ patients) patients with homozygous $\mathrm{p}$. $(\mathrm{R} 391 \mathrm{G})$ pathogenic variants should also be detected amongst PXE patients. This was indeed recently reported for one 
medRxiv preprint doi: https://doi.org/10.1101/2020.11.26.20236489; this version posted November 30, 2020. The copyright holder for this preprint (which was not certified by peer review) is the author/funder, who has granted medRxiv a license to display the preprint in perpetuity. All rights reserved. No reuse allowed without permission.

patient (49). However, it should be noted that this patient also suffered from beta-thalassemia, which was previously shown to lead in some cases to a PXE phenocopy in older patients (50).

There is a further line of evidence, supporting the severe phenotype caused by the p.(R391G) variant. Recessive LOF pathogenic variants of ENPP1 lead to generalized arterial calcification of infancy (GACI), a severe form of ectopic calcification. GACI is characterized by high mortality rate after birth without treatment with bisphosphonates (51). A strong relationship between PXE and GACI is supported by the reports of several patients with GACI phenotype and mutations in the $A B C C 6$ gene in the absence of ENPP1 mutations (37). It should be noted that there were patients diagnosed with GACI in different centers with p.(R391G) ABCC6 $(37,52)$. Although this variant has an AF of almost $1 \%$ in the general population, it is very unlikely that among the 34 unrelated GACI patients, tested for ABCC6 mutations in the absence of ENPP1 mutations, three patients would be carriers of the p.(R391G) variant only by chance without having a pathogenic effect. This further confirms that in the appropriate context this incompletely penetrant pathogenic variant has full expressivity.

Our in silico prediction indicated no splicing alteration of the ABCC6 RNA due to the c.1171A $>\mathrm{G}$ variant [p.(R391G)], which is at 5 bases from the end of the $9^{\text {th }}$ exon. Even if we assume in vivo a weak effect on the splicing, it might be tissue-specific. Therefore, splicing should be tested where the expression of ABCC6 is functionally relevant. Due to the lack of patient liver samples, splicing alterations were not tested experimentally. Of note, patients with incompletely penetrant splice site pathogenic variants typically have milder phenotype than patients with LOF mutations since the mutation often only affects the efficiency of splicing. This leads to a somewhat retained function due to the presence of some correctly spliced mRNA species (19). Our analysis found no difference in the expressivity of the incomplete penetrant p.(R391G) variant compared to LOF mutations, which further supports that this variant does not influence splicing.

The low penetrance of $\mathrm{p} .(\mathrm{R} 391 \mathrm{G})$ also suggests that in the gnomAD database containing genomic data from healthy individuals homozygous p.(R391G) variants are expected at a theoretical frequency of $6.1 / 100,000$ since the $\mathrm{AF}$ is $0.78 \%$ in that population. Indeed, we found 2 homozygous healthy individuals among the 63124 European individuals analyzed in the gnomAD database, which is not different from the expected frequency $(\mathrm{p}=0.58)$. However, this observation should be taken with caution since it is not completely excluded that patients with genetic diseases are also included in gnomAD (39). Additionally, it has been shown recently, that in some rare cases a very mild, eye-restricted form of PXE can develop in the elderly harboring the p.(R391G) pathogenic variant (47), which most probably remains undetected in most of the cases.

Trying to find an explanation for the incomplete penetrance at the molecular level we hypothesized that the p.(R391G) variant becomes a classical disease-causing pathogenic variant only if another intramolecular variant of ABCC6 is co-occurring. This hypothesis was further strengthened by the homology models indicating potential interactions between the residue and other residues of the protein $(47,53)$. However, when testing our PXE patient database for the co-occurring sequence variants we did not find any SNPs present systemically in the ABCC6 gene in cis position. This ruled out the hypothesis of an intra-protein interaction leading to the development of PXE or GACI in the presence of the p.(R391G) pathogenic variant. Another explanation for our findings could be an interaction of the ABCC6 proteins expressed from the two different alleles. The interaction 
medRxiv preprint doi: https://doi.org/10.1101/2020.11.26.20236489; this version posted November 30, 2020. The copyright holder for this preprint (which was not certified by peer review) is the author/funder, who has granted medRxiv a license to display the preprint in perpetuity. All rights reserved. No reuse allowed without permission.

would then be abolished by the p.(R391G) pathogenic variant only in the presence of a specific pathogenic variant on the other allele. Such an intermolecular mechanism leading to incomplete penetrance has been reported in the case of the NPHS2 gene (24). In this case, Tory et al. have previously identified an incomplete penetrance phenomenon and also revealed the mechanism. The p.(R229Q) pathogenic variant in the NPHS2 gene encoding podocin alters the dimerization of the protein only in the presence of certain pathogenic variants on the other allele (24). However, for the ABCC6 protein no such interaction or any indication of its di- or multimerization has ever been reported. Furthermore, we have not found any specific pathogenic variant pattern on the $2^{\text {nd }}$ allele (on a trans position), further disproving this scenario. The interallelic interaction between the two ABCC6 alleles involving the R391 residue was not supported either by a patient being reported previously with homozygous p.(R391G) pathogenic variant, or by the frequent cooccurrence of large $A B C C 6$ deletions or other truncating pathogenic variants on the other allele in trans position to R391G (49).

Ruling out these potential mechanisms, we hypothesized that incomplete penetrance of the p.(R391G) pathogenic variant can arise if ABCC6 is participating in a protein-protein interaction, that is crucial for the correct localization/function of ABCC6. Such an interaction partner has not yet been identified for ABCC6. However, in the ABCC gene family two well-known proteins (SUR1 and SUR2) are ion channel regulator proteins physically interacting with other membrane proteins $(54,55)$. It has also been shown, that CFTR interacts with several other proteins $(56,57)$. According to our hypothesis, the interaction between ABCC6 and the unidentified factor takes place through the R391 residue, which is in a highly conserved amino acid stretch, strengthening our hypothesis on its critical role (Figure 2). We hypothesize, that this interaction with the unknown protein would be ablated by the presence of the G391 variant only in the case when the interacting partner also has a rare sequence variant, unable to interact with G391 but still functional with the R391 residue. According to this theory, for the elimination of the interaction between the ABCC6 p.(R391G) and the other protein, both alleles of the interacting protein should be mutated, which would explain the very low penetrance of the p.(R391G) variant.

It should be emphasized that the putative interaction between ABCC6 and the yet unknown partner may occur at various levels. This interaction might take place temporarily during protein maturation or trafficking, could affect the localization, stability, turnover, or the plasma membrane retention of ABCC6. Last but not least, it may as well directly affect the primary physiological function of ABCC6, mediating cellular ATP efflux. Interestingly, an important proportion of ABCC6 missense variants are localization mutants, which retain their enzymatic activity if their plasma membrane localization is rescued. Hypothesizing that the interaction partner of ABCC6 involved in the p.(R391G) pathogenesis is related to the maturation and localization of ABCC6 might even give hints about potential therapies with chemical chaperones, e.g. 4-phenyl-butyrate (4-PBA), an FDA approved drug. Indeed, 4-PBA was already shown to rescue some mislocalized pathogenic $\mathrm{ABCC} 6$ mutants retained in the $\operatorname{ER}(58,59)$.

ABCC6 is a transmembrane protein localized in the basolateral membrane (60), expressed mainly in hepatocytes, less in kidney and the gastrointestinal epithelial cells due to its transcriptional regulation governed by $\mathrm{HNF} 4 \alpha(61,62)$, but virtually absent from HEK293 cells. The direct transport of various substrates (e.g. $\mathrm{LTC}_{4}$ ) by ABCC6 was initially observed in a heterologous expression system but could not be confirmed later. It has been shown more recently that the 
medRxiv preprint doi: https://doi.org/10.1101/2020.11.26.20236489; this version posted November 30, 2020. The copyright holder for this preprint (which was not certified by peer review) is the author/funder, who has granted medRxiv a license to display the preprint in perpetuity. All rights reserved. No reuse allowed without permission.

protein promotes ATP release from hepatocytes to the bloodstream $(2,3)$, providing an indisputable explanation for the vast majority of the pathologic findings related to PXE. Yet importantly, the source of the extensive phenotypic heterogeneity observed in PXE has not yet been clarified unambiguously. Based on the incompletely penetrant ABCC6 variant identified here we propose that at least some of the heterogeneity can be explained by hypothesizing that ABCC6 requires a yet unidentified factor to exert its physiologic role. Our in vitro results indicate, that a simultaneous (pathogenic) variant of this putative interaction partner is necessary to abolish the function of the p.(R391G) variant. We assume, that in the commercially available HEK293 cell line the unknown interacting partner is present in homozygous wild type or heterozygous form as the function of the variant was not altered. We estimate that the homozygous mutant variant form of the interacting partner is expected to be rare (only $2 \%$ according to the penetrance of p.(R391G)). It should however be noted, that these functional tests were performed on the highly homologous rat protein, since it is more active than the human ABCC6 (3), making the detection of the potential differences between the wild-type and the mutant variants easier.

Collectively, our data have important clinical relevance for genetic counseling. First, the p.(R391G) pathogenic variant can cause either PXE or GACI. Second, the expected clinical phenotype is not different from any other known pathogenic variants leading to these diseases. Third, and most importantly, based on our study this pathogenic variant has low penetrance, which probably relies on sequence variants in other gene(s), thus the co-occurrence of p.(R391G) dependent disease in siblings is probably much less frequent than expected. Along these lines it seems reasonable to consider pathogenic variants of low or very low penetrance as risk factors, in the general sense.

In conclusion, our results on the p.(R391G) pathogenic variant are leading to a new hypothesis on the molecular mechanism of ABCC6 strongly suggesting the necessity of an interacting partner. Our experimental data opens new avenues in PXE research for the identification of interacting partner(s), which might become important biomarker(s) and pharmacological target(s) in PXE or other ectopic calcification disorders.

\section{Acknowledgements}

Authors gratefully acknowledge the collaboration of PXE patients and support of patient's Associations. This work is a result of a collaboration in the frame of the EuroSoftCalcNet COST Action (CA16-115). This work was supported by the National Research, Development and Innovation Office [NKFIH, FK131946], U.S Department of State [Fulbright Visiting Scholar Program], Hungarian Academy of Sciences [Bolyai Janos Fellowship BO/00730/19/8, Mobility grant] and by the UNKP-2020 New National Excellence Program of the Ministry for Innovation and Technology from the source of the NKFIH to FS. Further funding for this work was provided by PXE International and the National Institutes of Health Grant R01AR072695 (KvdW). SV is a PhD Fellow supported by a Methusalem grant from the Ghent University - Belgium (BOF08/01M01108). OMV is a Senior Clinical Investigator of the Research Foundation Flanders (FWO) - Belgium. MTA-SE Lendulet Research Grant (LP2015-11/2015) of the Hungarian Academy of Sciences, the KH125566, K135798 grants to KT and the Ministry of Human Capacities in Hungary in the frame of Institutional Excellence Program for Higher 
medRxiv preprint doi: https://doi.org/10.1101/2020.11.26.20236489; this version posted November 30, 2020. The copyright holder for this preprint (which was not certified by peer review) is the author/funder, who has granted medRxiv a license to display the preprint in perpetuity. All rights reserved. No reuse allowed without permission.

Education. Diagnosis and management of PXE DNA samples occurred at the PXE Reference Center (MAGEC Nord), Angers University Hospital, Angers, France, as a part of the French PXE cohort (ClinicalTrials.gov Identifier: NCT01446380). TA is a beneficiary of the NKFIH K132695 grant.

\section{Disclosure}

The authors have nothing to disclose.

\section{Legends}

Figure 1. Enrichment and severity of p.(R391G) pathogenic variant in the European PXE patient population A) Enrichment of sequence variants in the patient population relative to the European non-Finnish population of gnomAD database. Each dot represents the AF of an individual sequence variant in the 2 databases in a logarithmic scale. Solid, dashed, and punctuated lines represent 1x, 10x, and 100x enrichments, respectively. The incomplete penetrant p.(R391G) and p.(V787I) and the most frequent p.(R1141*) are also indicated. The sequence variants not represented on this logarithmic plot because they are absent from the gnomAD database are shown is Supplementary table 2. B) Relationship between Phenodex score and age. Open squares represent the sum of Phenodex scores of individual patients with 2 truncating pathogenic variants. Red circles represent patients with one p.(R391G) pathogenic variant. Black and red lines represent linear regression of the patients with $2 x \mathrm{LOF}$ and p.(R391G), respectively. Dotted lines matching the line colors show $95 \%$ confidence intervals for the linear regression.

Figure 2. A) Alignment of the sequence flanking the R391 amino acid residue in various vertebrates. The region adjacent to R391 of ABCC6 is highly conserved throughout evolution. The red rectangle indicates the alignment of R391, which is identical in all species analyzed from human to zebrafish and electric eel. Of note, in the two latter species there are two ABCC6 genes. B) Alignment of the sequence flanking the ABCC6 R391 amino acid residue in various members of the ABCC family in human. The red rectangle indicates the R391 and its two neighbors.

Figure 3. In vitro characterization of the human ABCC6 p.(R391G) equivalent rat ABCC6 R389G pathogenic variant. A) Overexpression of the wild-type and rat p.(R389G) mutant ABCC6 in HEK293 cells. $5 \mu \mathrm{g}$ protein of total cell lysates were shown on a Western-blot. The A2 clone of rat ABCC6 R389G mutant was selected for further analysis based on its similar expression level compared to that of the wild type rat ABCC6. B) Representative images showing the subcellular localization of the overexpressed wild-type and p.(R389G) mutant ABCC6 in HEK293 cells by confocal microscopy done in duplicates. Panels a-d show parental HEK293, e-h HEK293 cells overexpressing the wild type rat ABCC6 and i-1 HEK293 cells overexpressing p.(R389G) mutant rat ABCC6. Green; rat ABCC6, red: plasma membrane marker Na-K ATPase, blue Dapi staining. C) ATP efflux of the wild-type and R389G mutant Abcc6 overexpressed in HEK293 cells. D) PPi accumulation in the medium of HEK293 cells overexpressing the wild type or R389G rat ABCC6 after 24 hours incubation. Data in $\mathrm{C}$ and D depict the means +/- SE of representative experiments performed in octuple $(n=8)$ in two independent experiments. 
medRxiv preprint doi: https://doi.org/10.1101/2020.11.26.20236489; this version posted November 30, 2020. The copyright holder for this

\section{References}

1. Favre G, Laurain A, Aranyi T, Szeri F, Fulop K, Le Saux O, et al. The ABCC6 Transporter: A New Player in Biomineralization. Int J Mol Sci. 2017;18(9).

2. Jansen RS, Duijst S, Mahakena S, Sommer D, Szeri F, Varadi A, et al. ABCC6-mediated ATP secretion by the liver is the main source of the mineralization inhibitor inorganic pyrophosphate in the systemic circulation-brief report. Arterioscler Thromb Vasc Biol. 2014;34(9):1985-9.

3. Jansen RS, Kucukosmanoglu A, de Haas M, Sapthu S, Otero JA, Hegman IE, et al. ABCC6 prevents ectopic mineralization seen in pseudoxanthoma elasticum by inducing cellular nucleotide release. Proc Natl Acad Sci U S A. 2013;110(50):20206-11.

4. Rutsch F, Ruf N, Vaingankar S, Toliat MR, Suk A, Hohne W, et al. Mutations in ENPP1 are associated with 'idiopathic' infantile arterial calcification. Nat Genet. 2003;34(4):379-81.

5. Back M, Aranyi T, Cancela ML, Carracedo M, Conceicao N, Leftheriotis G, et al. Endogenous Calcification Inhibitors in the Prevention of Vascular Calcification: A Consensus Statement From the COST Action EuroSoftCalcNet. Front Cardiovasc Med. 2018;5:196.

6. Dedinszki D, Szeri F, Kozak E, Pomozi V, Tokesi N, Mezei TR, et al. Oral administration of pyrophosphate inhibits connective tissue calcification. EMBO Mol Med. 2017;9(11):1463-70.

7. Ringpfeil F, Lebwohl MG, Christiano AM, Uitto J. Pseudoxanthoma Elasticum: Mutations in the MRP6 Gene Encoding a Transmembrane ATP-binding Cassette (ABC) Transporter. Proceedings of the National Academy of Sciences of the United States of America. 2000;97(11).

8. Bergen AA, Plomp AS, Schuurman EJ, Terry S, Breuning M, Dauwerse H, et al. Mutations in ABCC6 Cause Pseudoxanthoma Elasticum. Nature genetics. 2000;25(2).

9. Le Saux O, Urban Z, Tschuch C, Csiszar K, Bacchelli B, Quaglino D, et al. Mutations in a Gene Encoding an ABC Transporter Cause Pseudoxanthoma Elasticum. Nature genetics. 2000;25(2).

10. De Vilder EYG, Cardoen S, Hosen MJ, Le Saux O, De Zaeytijd J, Leroy BP, et al. Pathogenic variants in the ABCC6 gene are associated with an increased risk for ischemic stroke. Brain Pathol. 2018;28(6):822-31.

11. Köblös G, Andrikovics H, Prohászka Z, Tordai A, Váradi A, Arányi T. The R1141X Loss-of-Function Mutation of the ABCC6 Gene Is a Strong Genetic Risk Factor for Coronary Artery Disease. Genet Test Mol Biomarkers. 142010. p. 75-8.

12. Legrand A, Cornez L, Samkari W, Mazzella JM, Venisse A, Boccio V, et al. Mutation spectrum in the ABCC6 gene and genotype-phenotype correlations in a French cohort with pseudoxanthoma elasticum. Genet Med. 2017;19(8):909-17.

13. Larusso J, Ringpfeil F, Uitto J. Pseudoxanthoma Elasticum: A Streamlined, EthnicityBased Mutation Detection Strategy. Clinical and translational science. 2010;3(6).

14. Moitra K, Garcia S, Jaldin M, Etoundi C, Cooper D, Roland A, et al. ABCC6 and Pseudoxanthoma Elasticum: The Face of a Rare Disease From Genetics to Advocacy. International journal of molecular sciences. 2017;18(7). 
medRxiv preprint doi: https://doi.org/10.1101/2020.11.26.20236489; this version posted November 30, 2020. The copyright holder for this preprint (which was not certified by peer review) is the author/funder, who has granted medRxiv a license to display the preprint in perpetuity.

15. Moore, AT., Fitzke, F., Jay, M., et al. Autosomal dominant retinitis pigmentosa with apparent incomplete penetrance: a clinical, electrophysiological, psychophysical, and molecular genetic study. The British journal of ophthalmology. 1993;77(8).

16. Ahluwalia JK, Hariharan M, Bargaje R, Pillai B, Brahmachari V. Incomplete Penetrance and Variable Expressivity: Is There a microRNA Connection? BioEssays : news and reviews in molecular, cellular and developmental biology. 2009;31(9).

17. Zlotogora J. Penetrance and Expressivity in the Molecular Age. Genetics in medicine : official journal of the American College of Medical Genetics. 2003;5(5).

18. Venturini G, Rose AM, Shah AZ, Bhattacharya SS, Rivolta C. CNOT3 Is a Modifier of PRPF31 Mutations in Retinitis Pigmentosa With Incomplete Penetrance. PLoS genetics. 2012;8(11).

19. Thauvin-Robinet C, Munck A, Huet F, Génin E, Bellis G, Gautier E, et al. The Very Low Penetrance of Cystic Fibrosis for the R117H Mutation: A Reappraisal for Genetic Counselling and Newborn Screening. Journal of medical genetics. 2009;46(11).

20. Minikel EV, Vallabh SM, Lek M, Estrada K, Samocha KE, Sathirapongsasuti JF, et al. Quantifying prion disease penetrance using large population control cohorts. Sci Transl Med. 2016;8(322):322ra9.

21. Riazuddin S, Castelein CM, Ahmed ZM, Lalwani AK, Mastroianni MA, Naz S, et al. Dominant Modifier DFNM1 Suppresses Recessive Deafness DFNB26. Nature genetics. 2000;26(4).

22. Israel L, Wang Y, Bulek K, Della Mina E, Zhang Z, Pedergnana V, et al. Human Adaptive Immunity Rescues an Inborn Error of Innate Immunity. Cell. 2017;168(5).

23. Collet C, Laplanche JL, Page J, Morel H, Woimant F, Poujois A. High Genetic Carrier Frequency of Wilson's Disease in France: Discrepancies With Clinical Prevalence. BMC medical genetics. 2018;19(1).

24. Tory K, Menyhárd DK, Woerner S, Nevo F, Gribouval O, Kerti A, et al. Mutationdependent Recessive Inheritance of NPHS2-associated Steroid-Resistant Nephrotic Syndrome. Nature genetics. 2014;46(3).

25. Wright CF, West B, Tuke M, Jones SE, Patel K, Laver TW, et al. Assessing the Pathogenicity, Penetrance, and Expressivity of Putative Disease-Causing Variants in a Population Setting. American journal of human genetics. 2019;104(2).

26. Miko A, Kaposi A, Schay G, Balogh E, Seidl D, Schnabel KK, et al., editors. Poster Nr:

1326 Interallelic interactions in autosomal recessive disorders : A population-genetic and a molecular approach. American Society of Human Genetics 68 th Annual Meeting; 2018; San Diego.

27. Gheduzzi D, Guidetti R, Anzivino C, Tarugi P, Di Leo E, Quaglino D, et al. ABCC6 Mutations in Italian Families Affected by Pseudoxanthoma Elasticum (PXE). Human mutation. 2004;24(5).

28. Vanakker, OM., Leroy, BP., Coucke, P., et al. Novel clinico-molecular insights in pseudoxanthoma elasticum provide an efficient molecular screening method and a comprehensive diagnostic flowchart. Human mutation. 2008;29(1).

29. Pfendner E, Vanakker OM, Terry S, Vourthis S, McAndrew PE, McClain MR, et al. Mutation Detection in the ABCC6 Gene and Genotype-Phenotype Analysis in a Large International Case Series Affected by Pseudoxanthoma Elasticum. Journal of medical genetics. 2007;44(10). 
medRxiv preprint doi: https://doi.org/10.1101/2020.11.26.20236489; this version posted November 30, 2020. The copyright holder for this preprint (which was not certified by peer review) is the author/funder, who has granted medRxiv a license to display the preprint in perpetuity. All rights reserved. No reuse allowed without permission.

30. Pulkkinen L, Nakano A, Ringpfeil F, Uitto J. Identification of ABCC6 Pseudogenes on Human Chromosome 16p: Implications for Mutation Detection in Pseudoxanthoma Elasticum. Human genetics. 2001;109(3).

31. Symmons O, Váradi A, Arányi T. How Segmental Duplications Shape Our Genome: Recent Evolution of ABCC6 and PKD1 Mendelian Disease Genes. Molecular biology and evolution. 2008;25(12).

32. Hosen, MJ., Nieuwerburgh V, F., Steyaert, W., et al. Efficiency of exome sequencing for the molecular diagnosis of pseudoxanthoma elasticum. The Journal of investigative dermatology. 2015;135(4).

33. Geu-Flores F, Nour-Eldin HH, Nielsen MT, Halkier BA. USER fusion: a rapid and efficient method for simultaneous fusion and cloning of multiple PCR products. Nucleic Acids Res. 2007;35(7):e55.

34. Szeri F, Niaziorimi F, Donnelly S, Orndorff J, van de Wetering K. Generation of fully functional fluorescent fusion proteins to gain insights into ABCC6 biology. FEBS Lett. 2020.

35. Szeri F, Lundkvist S, Donnelly S, Engelke UFH, Rhee K, Williams CJ, et al. The Membrane Protein ANKH Is Crucial for Bone Mechanical Performance by Mediating Cellular Export of Citrate and ATP. PLoS genetics. 2020;16(7).

36. Uitto J, Li Q, Jiang Q. Pseudoxanthoma Elasticum: Molecular Genetics and Putative Pathomechanisms. The Journal of investigative dermatology. 2010;130(3).

37. Nitschke Y, Baujat G, Botschen U, Wittkampf T, du Moulin M, Stella J, et al. Generalized Arterial Calcification of Infancy and Pseudoxanthoma Elasticum Can Be Caused by Mutations in Either ENPP1 or ABCC6. American journal of human genetics. 2012;90(1). 38. Omarjee L, Nitschke Y, Verschuere S, Bourrat E, Vignon MD, Navasiolava N, et al. Severe Early-Onset Manifestations of Pseudoxanthoma Elasticum Resulting From the Cumulative Effects of Several Deleterious Mutations in ENPP1, ABCC6 and HBB: Transient Improvement in Ectopic Calcification With Sodium Thiosulfate. The British journal of dermatology. 2019.

39. Karczewski KJ, Francioli LC, Tiao G, Cummings BB, Alföldi J, Wang Q, et al. The Mutational Constraint Spectrum Quantified From Variation in 141,456 Humans. Nature. 2020;581(7809).

40. Rave-Harel N, Kerem E, Nissim-Rafinia M, Madjar I, Goshen R, Augarten A, et al. The Molecular Basis of Partial Penetrance of Splicing Mutations in Cystic Fibrosis. American journal of human genetics. 1997;60(1).

41. Moolman JA, Reith S, Uhl K, Bailey S, Gautel M, Jeschke B, et al. A Newly Created Splice Donor Site in Exon 25 of the MyBP-C Gene Is Responsible for Inherited Hypertrophic Cardiomyopathy With Incomplete Disease Penetrance. Circulation. 2000;101(12).

42. Schubert EL, Strong LC, Hansen MF. A Splicing Mutation in RB1 in Low Penetrance Retinoblastoma. Human genetics. 1997;100(5-6).

43. Cogan J, Austin E, Hedges L, Womack B, West J, Loyd J, et al. Role of BMPR2 Alternative Splicing in Heritable Pulmonary Arterial Hypertension Penetrance. Circulation. 2012;126(15).

44. Wang M, Marín A. Characterization and Prediction of Alternative Splice Sites. Gene. 2006;366(2).

45. Thompson JD, Higgins DG, Gibson TJ. CLUSTAL W: Improving the Sensitivity of Progressive Multiple Sequence Alignment Through Sequence Weighting, Position-Specific Gap Penalties and Weight Matrix Choice. Nucleic acids research. 1994;22(22). 
medRxiv preprint doi: https://doi.org/10.1101/2020.11.26.20236489; this version posted November 30, 2020. The copyright holder for this preprint (which was not certified by peer review) is the author/funder, who has granted medRxiv a license to display the preprint in perpetuity. All rights reserved. No reuse allowed without permission.

46. Ran Y, Zheng A, Thibodeau PH. Structural Analysis Reveals Pathomechanisms Associated With Pseudoxanthoma Elasticum-Causing Mutations in the ABCC6 Transporter. The Journal of biological chemistry. 2018;293(41).

47. Issa PC, Tysoe C, Caswell R. Late-onset Pseudoxanthoma Elasticum Associated With a Hypomorphic ABCC6 Variant. American journal of ophthalmology. 2020.

48. Verschuere, S., Navassiolava, N., Martin, L., et al. Reassessment of causality of ABCC6 missense variants associated with pseudoxanthoma elasticum based on Sherloc. Genetics in medicine : official journal of the American College of Medical Genetics. 2020.

49. Boraldi F, Lofaro FD, Costa S, Moscarelli P, Quaglino D. Rare Co-occurrence of BetaThalassemia and Pseudoxanthoma elasticum: Novel Biomolecular Findings. Frontiers in medicine. 2020;6.

50. Hamlin N, Beck K, Bacchelli B, Cianciulli P, Pasquali-Ronchetti I, Le Saux O. Acquired Pseudoxanthoma elasticum-like syndrome in beta-thalassaemia patients. Br J Haematol. 2003;122(5):852-4.

51. Ruf N, Uhlenberg B, Terkeltaub R, Nürnberg P, Rutsch F. The Mutational Spectrum of ENPP1 as Arising After the Analysis of 23 Unrelated Patients With Generalized Arterial Calcification of Infancy (GACI). Human mutation. 2005;25(1).

52. Li Q, Brodsky JL, Conlin LK, Pawel B, Glatz AC, Gafni RI, et al. Mutations in the ABCC6 Gene as a Cause of Generalized Arterial Calcification of Infancy: Genotypic Overlap With Pseudoxanthoma Elasticum. The Journal of investigative dermatology. 2014;134(3).

53. Hosen MJ, Zubaer A, Thapa S, Khadka B, De Paepe A, Vanakker OM. Molecular Docking Simulations Provide Insights in the Substrate Binding Sites and Possible Substrates of the ABCC6 Transporter. PloS one. 2014;9(7).

54. Ding D, Wang M, Wu JX, Kang Y, Chen L. The Structural Basis for the Binding of Repaglinide to the Pancreatic K ATP Channel. Cell reports. 2019;27(6).

55. Foster MN, Coetzee WA. KATP Channels in the Cardiovascular System. Physiological reviews. 2016;96(1).

56. Haggie PM, Kim JK, Lukacs GL, Verkman AS. Tracking of Quantum Dot-Labeled CFTR Shows Near Immobilization by C-terminal PDZ Interactions. Molecular biology of the cell. 2006;17(12).

57. Ko SB, Zeng W, Dorwart MR, Luo X, Kim KH, Millen L, et al. Gating of CFTR by the STAS Domain of SLC26 Transporters. Nature cell biology. 2004;6(4).

58. Saux L, O., Fülöp, K., Yamaguchi, Y., et al. Expression and in vivo rescue of human ABCC6 disease-causing mutants in mouse liver. PloS one. 2011;6(9).

59. Pomozi V, Brampton C, Szeri F, Dedinszki D, Kozak E, van de Wetering K, et al. Functional Rescue of ABCC6 Deficiency by 4-Phenylbutyrate Therapy Reduces Dystrophic Calcification in Abcc6(-/-) Mice. J Invest Dermatol. 2017;137(3):595-602.

60. Pomozi V, Le Saux O, Brampton C, Apana A, Ilias A, Szeri F, et al. ABCC6 is a basolateral plasma membrane protein. Circ Res. 2013;112(11):e148-51.

61. de Boussac H, Ratajewski M, Sachrajda I, Köblös G, Tordai A, Pulaski L, et al. The ERK1/2-hepatocyte Nuclear Factor 4alpha Axis Regulates Human ABCC6 Gene Expression in Hepatocytes. The Journal of biological chemistry. 2010;285(30).

62. Arányi T, Ratajewski M, Bardóczy V, Pulaski L, Bors A, Tordai A, et al. Identification of a DNA Methylation-Dependent Activator Sequence in the Pseudoxanthoma Elasticum Gene, ABCC6. The Journal of biological chemistry. 2005;280(19). 
medRxiv preprint doi: https://doi.org/10.1101/2020.11.26.20236489; this version posted November 30, 2020. The copyright holder for this preprint (which was not certified by peer review) is the author/funder, who has granted medRxiv a license to display the preprint in perpetuity. All rights reserved. No reuse allowed without permission.

Figure 1.

A

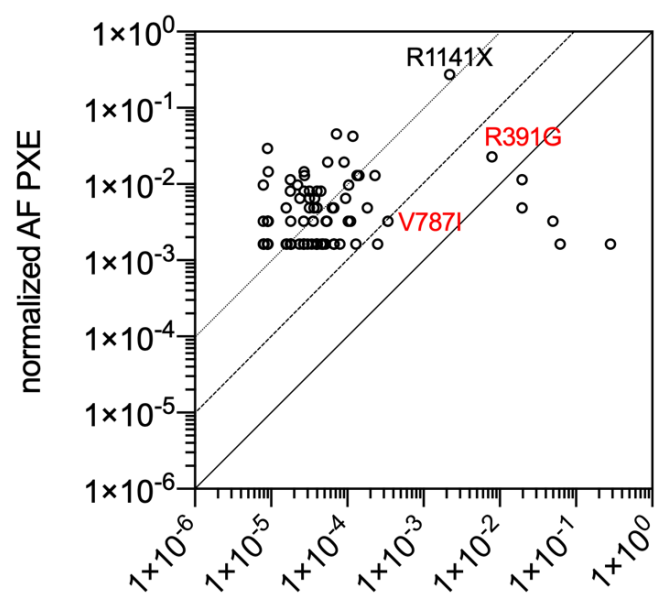

B

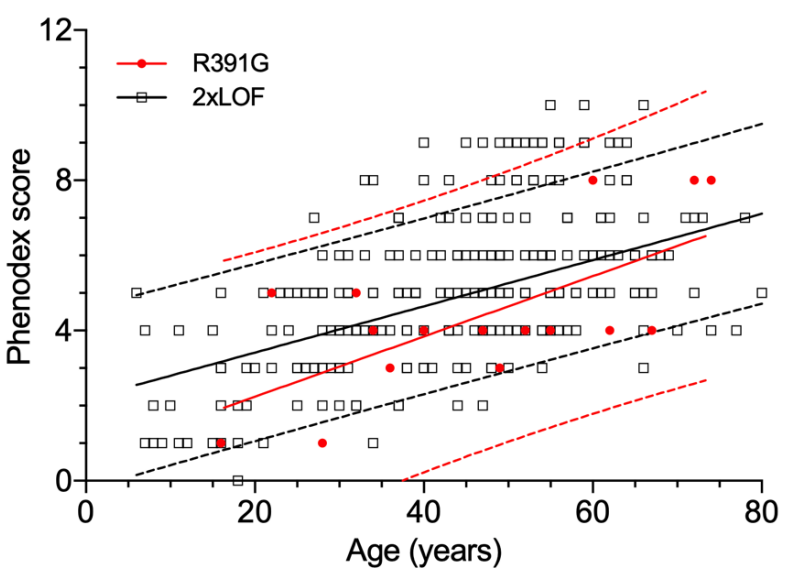

normalized AF gnomAD 
medRxiv preprint doi: https://doi.org/10.1101/2020.11.26.20236489; this version posted November 30, 2020. The copyright holder for this preprint (which was not certified by peer review) is the author/funder, who has granted medRxiv a license to display the preprint in perpetuity. All rights reserved. No reuse allowed without permission.

Figure 2.

A

Rat
Mouse
Human
Goat
Sheep
A.marmota
Pig
Platypus
Chick
Duck
Zebrafish/A
Zebrafish/B2
E.eel/A
E.eel/B2

YMYRVKVLQMRLRTAITGLVYRKVLVLSSGSRKSSAAGDVVNLVSVDVQ HMYRAKVLQMRLRTAITGLVYRKVLVLSSGSRKSSAAGDVVNLVSVDIQ NMYRLKVLQMRLRSAITGLVYRKVLALSSGSRKASAVGDVVNLVSVDVQ HMYRLKVLQMRLRTAVTGLVORKVLALSSSSRKSSAVGDVVNLVSVDVQ HMYRLKVLQMRLRTAVTGLVY RKVLALSSSSRKSSAVGDVVNLVSVDVQ FMYRVKVLQMRLRTAITGLVYRKVLALSSSARKASAVGDVVNLLSVDVP HMYRLKVLQMRLRTALIGLVYRKVLALSSSSRKASAVGDAVNVASVDVQ YMYVCFVLGMRLKTALVGLVY RKVLALSSAARKATAVGE IVNLVSVDVQ YMYMCLVLGLRLKTAVTGLVYRKILTMSNASRKAVTVGEIVNLVSVDVQ YMYMCLVLGLKLKTVVTGLVYRKILIMSNASRKAVTVGEIVNLISVDVQ YTYTCFTVGMRVKTAVMGLVYRKSLVMNSSARRTCTVGE IVNLVSADTQ YMYTCLTVGMRVKTAVMGLVYRKSLVINSAARKTCTVGE IVNLVSADTQ YMYSCF SVGMRVKTAVMGLVYRKSLVLTSAARRTCTVGEIVNLVSADTQ YMYTCFTVGMRVKTAIMGLIYRKTLIINSAARRACTVGEIVNLVSADTQ

* : : : : : : : : **: ** * : ..: : : : :.*:**:***

$\mathrm{ABCC} 1$

$\mathrm{ABCC} 3$

$\mathrm{ABCC} 2$

ABCC6

$\mathrm{ABCC} 4$

$\mathrm{ABCC} 7$

$\mathrm{ABCC} 9$

$A B C C 5$

$\mathrm{ABCC} 8$
--VLHQYFHICFVSGMRIKTA-VIGAVYRK LVITNS--ARKSSTVGEIVNLMSVDAQRF

--ILQHYYHYIFVTGVKFRTG-IMGV] YRK/LVITNS--VKRASTVGEIVNLMSVDAQRF

--CLQCYFQLCFKLGVKVRTA-IMASIYKK/LTLSNL--ARKEYTVGETVNLMSVDAQKL -NMYRLKVLQMRLRSA-ITGLV YRK 'LALSSG--SRKASAVGDVVNLVSVDVQ---LHHLYFYHVQCAGMRLRVA-MCHMI YRK/LRLSNM--AMGKTTTGQIVNLLSNDVNKF --LLHPAIFGLHHIGMQMRIA-MFSLI YKK L LKLSSR--VLDKISIGQLVSLLSNNLNKF --FLQASYYVTIETGINLRGA-LLAM] YNK: LRLSTSNLSMGEMTLGQINNLVAIETNQL --PAFMVKHLLEYTQATESNL-QYSLILVL('LLLTEIVRSWSLALTWALNYRTGVRLRGA YWWMNAFIKTAHKKPIDLRAIGKLPIA MRAI TNYQRLCEAFDAQVRKDIQGTQGARAIWQ 
medRxiv preprint doi: https://doi.org/10.1101/2020.11.26.20236489; this version posted November 30, 2020. The copyright holder for this preprint (which was not certified by peer review) is the author/funder, who has granted medRxiv a license to display the preprint in perpetuity.

All rights reserved. No reuse allowed without permission.

Figure 3.

A

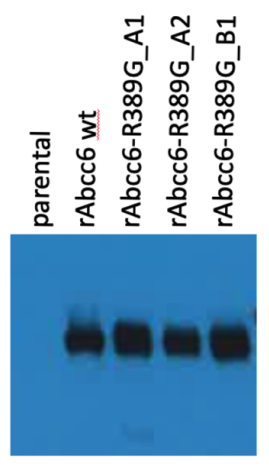

B
C

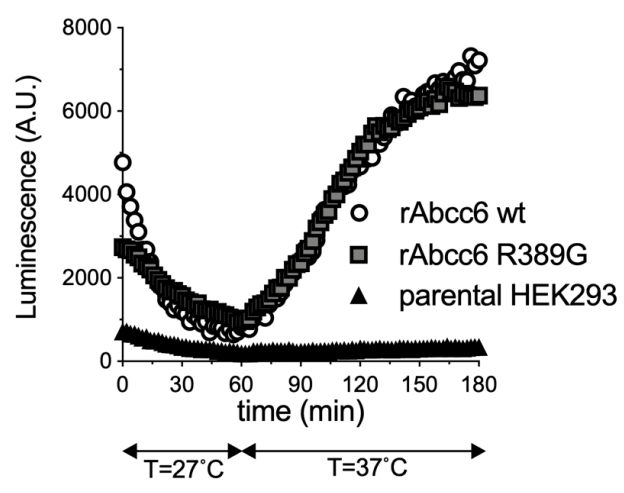

D

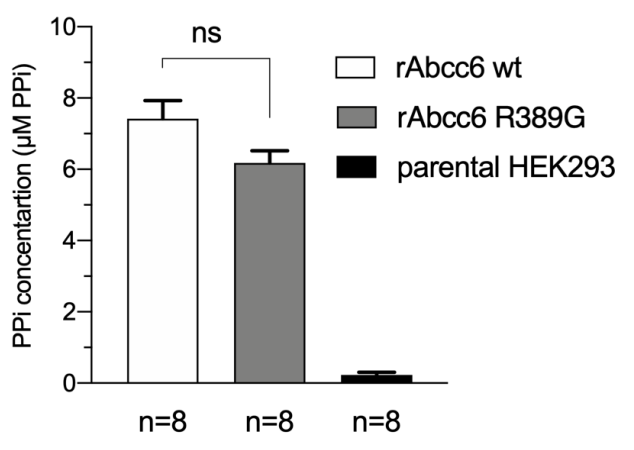

